\title{
PROJETOS POLÍTICOS NAS INTERPRETAÇÕES DO BRASIL DA PRIMEIRA METADE DO SÉCULO XX
}

Maria Stella Bresciani ${ }^{1}$

IFCH - Unicamp

\begin{abstract}
Resumo
Embora apoiados em pressupostos analíticos diferentes, Paulo Prado (Retrato do Brasil, 1928), Sérgio Buarque de Holanda (Raízes do Brasil, 1936), Gilberto Freyre (Casa grande \& senzala, 1933) e Caio Prado Junior (Evolução política do Brasil, 1934), entre muitos outros estudiosos da primeira metade do século XX, chegaram a leituras da sociedade brasileira em grande parte coincidentes com a de Francisco de Oliveira Vianna exposta no volume I de Populações meridionais do Brasil (1920), O idealismo na evolução política do Império e da República (1922) e outros escritos seus. Os autores partem do mesmo pressuposto: a incompatibilidade entre instituições, pensamento e ideias liberais, - proposições consideradas avançadas por terem sido formuladas em países “mais civilizados” -, e a situação, ou a "realidade brasileira”, adjetivada de atrasada, patriarcal, patrimonial, semifeudal, por nela inexistir a figura política do cidadão, imprescindível para a vigência efetiva de instituições, tal como preconizava a Constituição republicana de 1891. Formava-se em seus escritos a figura do brasileiro como um homem descontente consigo mesmo, ressentido com seus pais colonizadores devido à herança maldita aqui deixada. Essa poderosa figura negativa situou a questão da cidadania no núcleo do debate e serviu de eixo argumentativo para seus diferentes projetos políticos.
\end{abstract}

\footnotetext{
${ }^{1}$ Este trabalho constitui desdobramento de parte do livro de minha autoria O charme da ciência e a sedução da objetividade. Oliveira Vianna entre intérpretes do Brasil. São Paulo: Ed. Unesp/ Fapesp, 2005 (2007) e contou com apoio de Bolsa Produtividade CNPq.
} 
O volume Idées do Dictionnaire critique de la Révolution française de François Furet e Mona Ozouf indica quão moderna é a noção de projeto em política. ${ }^{2}$ No verbete Révolution os autores afirmam que "os homens da Revolução desejaram encontrar no passado a profecia do grande acontecimento que viviam. (...) Uma busca algo artificial e decepcionante, pois com frequência se retiravam citações de seu contexto, embora alguns raros escritos parecessem fornecer a demonstração esperada.” Nesse mesmo registro, prosseguem Furet e Ozouf, nada parece mais eloquente do que o escrito de Mably - Droits et devoirs du citoyen - no qual, em 1750, coloca em diálogo um francês e um inglês indagando-se sobre o sentido da história. O resultado imaginado é o de um cenário com a promessa de um belo futuro. Ao pessimismo fatalista do francês Mably contrapõe o otimismo do lorde inglês com sua história de vontade e de esperança: o bom cidadão pode agir de modo a tornar as revoluções "úteis à pátria”. Seus conselhos compõem um “programa” - a convocação dos Estados Gerais poderia sacudir a fatalidade histórica e extirpar os abusos, enfraquecer as prerrogativas reais e institucionalizar os direitos da nação. Furet e Ozouf dizem em seguida que, a despeito dessa imagem projetada para um tempo futuro, o próprio Mably se manteve fiel à noção astronômica de revolução, a do retorno a formas anteriores: "nos assuntos humanos, a revolução encaminha as coisas a seu ponto de partida, ou seja, ao retorno eterno a formas políticas devidamente repertoriadas. Afinal, prosseguem os autores, essa foi a interpretação dada a dois acontecimentos referenciais - a "gloriosa” revolução inglesa de 1688, foi considerada, do ponto de vista huguenote, como revolução-retorno e do ponto de vista do rei absolutista, como uma a mais na história inglesa marcada por alternância de reinos felizes e infelizes; mesmo a americana, que mereceu a denominação de "revolução feliz", manteve contudo o sentido de restauração das liberdades inglesas. ${ }^{3}$

Seria, pois, no decorrer dos eventos franceses dos anos 1790, quando o "velho mundo" veio abaixo, que a palavra revolução teve seu sentido ressignificado para a acepção de "instauração", de movimento em direção ao futuro e a uma nova organização política e social. Hannah Arendt também se deteve na inversão de sentido de "revolução” no desenrolar dos acontecimentos franceses

\footnotetext{
${ }^{2}$ FURET, François \& OZOUF, Mona. Idées. Dictionnaire critique de la Révolution française. Paris: Flammarion, 1992.

${ }^{3}$ FURET, F. \& OZOUF, M. Idées. Dictionnaire critique de la Révolution française, op. cit., p. 415-419.
} 
e afirma: a acepção corrente relacionada aos movimentos dos astros, ou seja, a volta a um estágio anterior, se modifica na intenção projetiva de "busca da liberdade"; logo depois, entretanto, sob a pressão da "questão social”, sofre nova ressignificação na acepção dada pelos jacobinos de "busca da felicidade”. Esse último deslocamento, ao deslocar o sentido da palavra, trouxe para a esfera pública o domínio dos sentimentos. ${ }^{4}$ Assumiam, assim, o cerne das ações revolucionárias, as noções de compaixão e de piedade, antes restritas à esfera da intimidade, e impeliam os homens na direção dos "fracos” para com eles estabelecer vínculos de "solidariedade”. Arendt argumenta que a noção de "solidariedade" encontra força persuasiva ao definir sua sede na esfera da razão e trazer para essa esfera o conceito de multidão, fosse ela de classe, de nação, ou mesmo de toda a humanidade. Diversamente da compaixão (uma paixão) e da piedade (um sentimento), a solidariedade assumiu lugar na praça pública, e passou a inspirar e a guiar a ação dos revolucionários. ${ }^{5}$

\section{Viagens e projeções utópicas}

Essa breve digressão traz para o debate o significado moderno do termo “revolução” em sua instauração/projeção de um tempo outro, um tempo futuro agenciado no presente. Inversão que encontra paralelo em outro registro político, os amplos domínios das narrativas utópicas. No início do século XVI, Thomas More desejava mudanças radicais nas sociedades europeias, "aspiro mais do que espero", disse ele ao final da conversa na qual Rafael Hitlodeu narra sua experiência na ilha Utopia. A imagem da sociedade outra transportada para os domínios da verossimilhança pelas descobertas dos navegadores faz dela uma projeção inscrita como possibilidade futura. Nos domínios das narrativas utópicas, ocorre, no decorrer do século XVIII, um deslocamento fundamental: o espelhamento de duas sociedades contemporâneas da narrativa de More, separadas por espaços imaginários, cuja diferença se estrutura em suas respectivas histórias, cede lugar à projeção no tempo futuro de mudanças no mesmo espaço ou país. Em suma, os argumentos das narrativas projetam de modo explícito o olhar para um tempo futuro que substitui o deslocamento no espaço. Mantém,

\footnotetext{
${ }^{4}$ A noção de revolução foi tema de reflexão de Hannah Arendt amplamente tratado em ARENDT, Hannah. On revolution. Nova York: Viking Press, 1963, gerando polêmica, mas também numerosos adeptos de seus argumentos.

${ }^{5}$ A noção de “revolução” é tema de reflexão do capítulo 1; a “questão social”, do capítulo 2.
} 
entretanto, a mesma intenção sugestiva. Nas palavras de Bronislaw Baczko, as representações utópicas “dirigem o olhar na direção de uma 'sociedade outra', oposta à sociedade existente, reconciliada com a razão, a história, a felicidade”. ${ }^{6}$

A viagem narrada por Hitlodeu constitui trajetória necessária à narrativa sobre um país imaginado. No texto escrito, o aspecto visual da disposição física das cidades entrelaça-se com as leis - a ilha da Utopia de Thomas More, com suas cinquenta e quatro cidades, mas principalmente sua capital Amaurota, é dada a ver; quando descrita, permite a comparação, expõe afinidades e oposições entre a cidade imaginada e a sociedade em que vive seu leitor, incita à comparação, mobiliza a ação ao prefigurar a "alteridade possível”. ${ }^{7}$ Já LouisSébastien Mercier, ao deslocar sua narrativa para a projeção de um tempo futuro, permitiu imaginar uma "outra sociedade” no mesmo espaço físico da capital francesa. Adormecido por volta de 1770, o narrador o acorda no ano 2440 e encontra uma Paris outra, modificada pelo "progresso". Assim, diz Baczko, "a utopia vinculada à ideia de progresso rompe com a insularidade física da ilha ou do tempo fechado sobre si mesmo, no sentido de que seu tempo se afirma como o da história universal”. Uma mesma história agora comandada pelo "progresso", "um movimento global e irresistível cuja finalidade repousa na atualização dos grandes valores que comandam o aperfeiçoamento do espírito humano", completa o autor. ${ }^{8}$

Pode-se dizer das narrativas utópicas - sejam insulares (a Utopia de More: versão em latim de 1516 e inglesa póstuma de 1551), ou projeções futuras (Mercier: L'Ann 2440, 1770) ou, ainda, vivenciadas em sonho na opção de William Morris (News from nowhere, 1891) - que se estruturam em cidades bem configuradas; a arquitetura fala uma linguagem universal, a das formas ordenadas, e em leis que constrangem, mas em nome da felicidade do povo. Nos anos da Revolução Francesa, o projeto republicano de um novo calendário (além da reforma dos pesos e medidas) sintetiza a projeção racional de uma nova era que se instala com o homem novo criado pela Revolução, o cidadão da cidade fundada em valores revolucionários. Nessas iniciativas se dá a inscrição da racionalidade do sistema decimal à linguagem revolucionária afetiva, sensível aos símbolos, linguagem de símbolos que atingem diretamente o coração.

\footnotetext{
${ }^{6}$ BACZKO, Bronislaw. Prefácio. Lumières de l’Utopie. Paris: Payot, 1978.

${ }^{7}$ MORE, Thomas. A Utopia. Os pensadores, vol. X. São Paulo: Abril Cultural, 1972, Livro Segundo. Da comunicação de Rafael Hitlodeu.

${ }^{8}$ BACZKO, Bronislaw, op. cit., p. 15-19, 155-168.
} 
Linguagem que, entretanto, recorre à racionalidade na projeção da nova cidade e na proposta do novo calendário que instaura um tempo novo, ambas vinculadas à simbologia revolucionária apta a dominar a imaginação, na qual se incluem as festas revolucionárias como novo espaço da solidariedade cidadã. ${ }^{9}$

Concepções denominadas utópicas permaneceram no cerne de projeções políticas no século XIX sempre apoiadas no binômio da configuração do espaço físico da cidade e das leis ou da figura paradigmática do grande legislador. Sem dúvida, a imagem da sociedade existente, atravessada por conflitos sociais, narrada ou representada iconograficamente se apoia na força das imagens; dirige as pessoas para um objetivo e age sobre a inteligência humana ao apresentar a projeção da possível superação. ${ }^{10}$ Muda, contudo, o paradigma quando, no século XIX, as projeções de sociedades ideais são apresentadas por seus autores como teorias sociais e/ou verdades fundamentadas em critérios científicos e suas projeções se inserem nas "leis universais da evolução histórica”. Por vezes, como na narrativa de Cabet, repete-se o recurso à viagem imaginária, mas se trata, dirá Baczko, de expediente literário. ${ }^{11}$

Ainda que não insular, o espaço fechado ou o tempo fechado sobre si mesmo se mantém nos projetos de Owen em New Lanark, nos falanstérios de Fourier, nas cidades-jardins inglesas de Howard ou até na Cité industrielle de Tony Garnier, como projeção exemplar da cidade industrial capaz de conciliar capital e trabalho. Avançam século XX adentro, com Frank Loyd Wright e Le Corbusier, na intenção de expressar o poder e a beleza da tecnologia moderna ou em projetos orientados pela ideia de justiça social, na projeção de cidades ideais acompanhadas de programas detalhados e radicais de distribuição de riqueza e poder.

\footnotetext{
${ }^{9}$ BACZKO, Bronislaw, op. cit., p. 209-217.

${ }^{10} \mathrm{O}$ poder de sedução da imaginação e formas de utilizá-lo de modo a emocionar e conduzir pessoas a uma finalidade, mesmo não explicitada de antemão, é tema tratado por vários autores no século XVIII, dentre os quais, BURKE, Edmund. A philosophical inquiry into the origin of our ideas of sublime and beautiful (1756) e STAËL, Germaine de. Essai sur les fictions (1795). Cf. BRESCIANI. Stella. Le pouvoir de l'imagination: Du for intérieur aux moeurs publiques. Germaine de Staël et les fictions littéraires in Le for intérieur.In: HAROCHE, Claudine (org.). Paris: PUF, 1995 ${ }^{11}$ BACZKO, Bronislaw, op. cit., p. 217.
} 


\section{Análises e projeções políticas no Brasil dos anos 1920 e 1930}

Fiz para esse artigo um recorte no amplo domínio das projeções políticas de sociedades ideais desenhadas pelo traço do arquiteto e/ou pelas palavras dos pensadores políticos (juristas, historiadores, pré-sociólogos etc.). Escolhi quatro intelectuais brasileiros empenhados na primeira metade do século XX em elaborar projeções políticas cujo objetivo constituía fazer do Brasil uma nação apoiada em cidadãos bem formados, homens conscientes de direitos e deveres conjugando um objetivo comum. Em seus projetos utilizam um procedimento argumentativo semelhante ao das narrativas e projeções ideais: iniciam com a exposição da situação existente ou o tempo presente problemático e projetam a solução ideal em um futuro possível e exequível pela vontade política de transformação. Em suas análises, a sociedade presente e a projeção futura configuram-se imageticamente. $\mathrm{Na}$ exposição de seus projetos executam o movimento inverso ao seu próprio raciocínio. Iniciam a apresentação de seus argumentos com a análise do país em que vivem ou, nas figuras de linguagem correntes nesses anos de nacionalismo explícito, “da realidade nacional” e "da originalidade nacional”, para só após a exposição das mazelas e desajustes explicitarem suas projeções da possível nação plenamente configurada pela vontade política consciente. Procedimento que os obriga a um longo percurso pela formação do país desde seus primórdios, no qual identificam pecados de origem ou percalços no percurso, causadores da presente situação problemática, de modo a oferecerem ao leitor explicações que a justificam. Procedimento que permite expor a situação presente revelando o processo em que se insere para, na sequência, propor a fórmula adequada a superar a situação anômala, indesejada. Nesse procedimento invertem o próprio raciocínio: o ponto de partida é certamente a sociedade-nação ideal ou idealizada e seus pressupostos estruturadores - noções e conceitos utilizados na análise da sociedade no presente.

Francisco de Oliveira Vianna, Paulo Prado, Gilberto Freyre e Sérgio Buarque de Holanda são os quatro autores escolhidos e, dentre seus trabalhos recortamos os publicados nas décadas de 1920 e 1930, período de intenso debate e de enfrentamento de projetos políticos divergentes. Seus escritos tiveram ampla repercussão e, embora radicados em campos conceituais diferentes, permitem trabalhar com a hipótese da persistência de uma mesma busca - do cidadão brasileiro que consideram ainda mal formado, de um perfil nacional fincado em seus elementos formadores: o meio ambiente tropical, a presença de diversas 
raças e a interpretação do processo histórico interpretado a partir da chegada dos primeiros colonizadores.

Oliveira Vianna, bacharel em Direito, mantém o rótulo de autor maldito por sua participação ativa na formulação da legislação social e sindical do governo ditatorial do Estado Novo (1938-1945), embora sua extensa produção sobre a sociedade brasileira, do ponto de vista sociológico e jurídico, coincida em vários pontos com a de outros autores seus contemporâneos. Paulo Prado, representante da elite paulista, é mais lembrado como mecenas, pela presença ativa na Semana de Arte Moderna de 1922 e por suas afinidades com outros autores. Ao historiador Capistrano de Abreu abriu a riqueza de sua biblioteca de livros raros e manuscritos, ${ }^{12}$ a Gilberto Freyre presenteou com o Diário intimo de Vauthier, manuscrito comprado em viagem à França, no qual o engenheiro francês registrou sua estada de seis anos em Pernambuco. A Freyre também abriu a riquíssima coleção de documentos da primeira visitação do Santo Ofício, editada por Prado na série que leva o nome de seu tio Eduardo Prado. Gilberto Freyre, aluno de Frans Boas na Universidade de Columbia, é autor traduzido em vários idiomas; elogiado em 1967 por Antonio Candido na apresentação paradigmática à 5 a edição de Raízes do Brasil de Sérgio Buarque de Holanda, por seu "intuito anticonvencional” e ter escrito Casa-grande \& senzala (1936) em "composição libérrima”, ter adotado "franqueza no tratamento da vida sexual do patriarcalismo e a importância decisiva do escravo”, em suma "livro antecipador”. ${ }^{13}$ Por fim, Sérgio Buarque de Holanda, que na juventude cursou Direito e conviveu com os "modernistas” da Semana de 1922 em São Paulo, foi crítico ativo em resenhas de livros publicadas na grande imprensa antes de depois de Raízes do Brasil. Sua importante produção historiográfica estendeuse até a década de 1970.

Esses autores estiveram vinculados a projetos políticos diferentes e mesmo opostos, o que os fez adotarem noções diferentes como pressupostos de suas análises. E, contudo, a despeito dessa diferença fundamental, partem da mesma imagem da sociedade brasileira: a do descompasso entre instituições estruturadas em “ideias avançadas" - liberais federalistas - e a sociedade atrasada de feição patriarcal, patrimonialista. Sigamos o percurso analítico proposto por eles.

\footnotetext{
${ }^{12}$ CALIL, Carlos Augusto. Introdução a Retrato de Brasil de Paulo PRADO. São Paulo: Companhia das Letras, 1998, p. 9-10. A $1^{\text {a }}$ edição do livro é de 1928.

${ }^{13}$ CANDIDO, Antonio. O significado de Raízes do Brasil. In: HOLANDA, Sérgio Buarque. Raízes do Brasil. Rio de Janeiro: Livraria José Olympio Editora, 1969, p. XI-XII.
} 
Começo por Francisco de Oliveira Vianna e seu primeiro livro Populações Meridionais do Brasil de 1920 com sua opinião sobre as instituições políticas vigentes após a Constituição Republicana de 1891:14

Na sua obsessão de sumariarem o que de mais alto existe nos ideais da civilização ocidental, estes estupendos edificadores de regimes .... legislam para abstrações ... não para que as executem brasileiros (...) mas uma entidade abstrata, esse homem-utopia: o Cidadão - esplêndido boneco metafísico, armado de molas idealmente perfeitas e precisas. ${ }^{15}$

No início da década de 1920, Oliveira Vianna, contrapunha a posição assumida pelos legisladores do Brasil independente em sua crença no poder da lei escrita em formar cidadãos à sua própria convicção de que a lei só teria eficácia se tivesse por base a população do país em suas características ou seu caráter, na expressão usual da época. Sua posição é explícita:

Ora, nós homens de agora, tomados do espírito realístico e objetivo do nosso tempo, não podemos continuar a cultivar este ingênuo estado d'alma de estetas de Constituições. O nosso ideal não será mais a "harmonia", nem a "beleza"; mas sim a "conveniência" e a "adaptação". O que devemos querer não são regimes belos ou harmônicos, mas regimes convenientes e adaptados ao nosso povo e aos seus destinos no continente e no mundo. ${ }^{16}$

Populações Meridionais do Brasil constitui texto pioneiro em relação à proposta de alterar o ponto de vista para compreender e apresentar a história do país. ${ }^{17} \mathrm{O}$ autor parte da certeza de que "somos inteiramente diferentes das sociedades europeias (...) somos completamente outros. (...) sentimos como a ação do meio cósmico influi sobre a estrutura da sociedade. - Sob a amenidade dos nossos climas tropicais a vida se torna empresa fácil (...) é a natureza tropical, com sua prodigalidade que o (homem) sustenta." ${ }^{18}$ A essa certeza agrega um segundo pressuposto, a "convicção contrária ao preconceito da uniformidade atual do nosso povo”, o que o leva a dar continuidade aos estudos do também

\footnotetext{
${ }^{14}$ Citações retiradas de BRESCIANI, Maria Stella Martins. O charme da ciência e a sedução da objetividade, op. cit., p. 314-315.

${ }^{15}$ VIANNA, Oliveira. Pequenos estudos de psicologia social. $3^{\text {a }}$ ed. São Paulo/Rio de Janeiro/ Recife/Porto Alegre: Companhia Editora Nacional, p.145, 1ª ed. 1921.

${ }^{16}$ VIANNA, Oliveira. O idealismo da Constituição. $2^{\mathrm{a}}$ ed. São Paulo: Companhia Editora Nacional, 1939, p. 115-116, $1^{\text {a }}$ ed. 1920,

${ }^{17}$ VIANNA, Oliveira. Populações meridionais do Brasil. Rio de Janeiro: Paz e Terra, 1973; $1^{\text {a }}$ edição em 1920.

${ }^{18}$ VIANNA, Oliveira. Populações meridionais do Brasil, op. cit., p. 126-127.
} 
bacharel em Direito Alberto Torres e, ao mesmo tempo, dele discordar de sua suposição de uma "realidade nacional” única ou homogênea. Para Vianna, fazia-se necessário "levar em conta a diversidade dos habitats, (...) as variações regionais no caldeamento dos elementos étnicos e, principalmente”, acentua, "a inegável diferença das pressões históricas e sociais sobre a massa nacional, quando exercidas ao norte, ao centro e ao sul”. As três regiões prevalecentes na época lhe pareceram ainda amplas demais e o levaram a dedicar seu primeiro estudo a uma parte da região sul, que passou a denominar “centro-sul” - Minas Gerais, Rio de Janeiro e São Paulo - postergando a análise das populações dos estados do extremo sul do país. ${ }^{19}$

Outro pressuposto definido pelo autor diz respeito ao objeto de suas "investigações, as populações rurais", cuja "influência silenciosa, obscura, subterrânea" seria, a seu ver, as “matrizes da nacionalidade.” Não há nesse primeiro livro as longas digressões sobre as "raças" presentes na composição social brasileira, que lhe valeriam a denominação de racista, e às quais se dedicou em Raça $e$ assimilação, publicado em 1932, e no qual afirmava "somos uma nacionalidade, para cuja formação o índio e o negro entraram em contribuição copiosíssima”. ${ }^{20}$ Completa o quadro de Populações meridionais a afirmação de que "depois da abolição do trabalho servil em 88, o nosso povo entra numa fase de desorganização profunda e geral, sem paralelo em toda a sua história" o que justifica o recorte temporal não abranger o período republicano, que "perturbadíssimo por crises sociais, econômicas e políticas", exigiria um estudo a parte. No entanto, Oliveira Vianna não deixa de avançar pelo século XX ao afirmar que "há um século [desde a proclamação da independência em 1822] vivemos politicamente em pleno sonho”. A seu ver, os homens de Estado haviam abandonado os "métodos objetivos e práticos de administração e legislação [dos] estadistas coloniais”. Atribui essa mudança de perspectiva à "fascinação magnética” dos "nossos dirigentes, políticos, estadistas, legisladores, publicistas”, pelo "movimento democrático da Revolução Francesa, pelas agitações parlamentares

\footnotetext{
${ }^{19} \mathrm{O}$ volume 2 de Populações meridionais do Brasil. O campeador rio-grandense, só seria publicado em 1952, após a morte do autor em 1951. Os argumentos e citações que se seguem estão nas Palavras de prefácio, p. 13-21, datadas de novembro de 1918.

${ }^{20}$ VIANNA, Oliveira. Raça e assimilação. $4^{\mathrm{a}}$ ed. Rio de Janeiro: Livraria José Olympio Editora, 1959, p. 168. No mesmo ano publicava Evolução do povo brasileiro, estudo dividido em três partes: evolução da sociedade, evolução da raça e evolução das instituições políticas.
} 
inglesas, e o espírito liberal das instituições da República Americana". Os denomina "Esthetas de Constituições". ${ }^{21}$ Corolário de seu argumento:

Sob esse fascínio inelutável, perdem a noção objetiva do Brasil real e criam para uso deles um Brasil artificial, e peregrino, um Brasil de manifesto aduaneiro, made in Europe - sorte do cosmograma extravagante, sobre cujo fundo de florestas e campos, ainda por descobrir e civilizar, passam e repassam cenas e figuras tipicamente europeias.

Deixemos de lado sua concepção idealizada de uma Europa una e homogênea, adotada, aliás, de modo acrítico por outros analistas também comprometidos com a “objetividade” na análise da história brasileira, em particular se lembrarmos que justamente nesse interregno de duas grandes guerras, a selvageria expôs de modo exemplar o quanto se mantém sob a fina camada da civilidade europeia. Voltemos ao Brasil. Para Vianna, se vivíamos nas esferas das ideias e da política em pleno sonho, ou "como fumadores de ópio”, não seriam nas instituições e nas leis que o analista cioso em manter seu estudo no campo da objetividade encontraria a verdadeira sociedade brasileira ou em seus termos a "realidade brasileira". Oliveira Vianna transpõe assim a análise da história do Brasil da esfera dos eventos políticos, privilegiada até então pela historiografia, para os domínios da sociedade, sua estrutura econômica, usos e costumes da população:

Todo meu intuito é estabelecer a caracterização social do nosso povo, tão aproximada da realidade quanto possível, de modo a ressaltar quanto somos distintos dos outros povos, principalmente dos povos europeus, pela história, pela estrutura, pela formação particular e original.

Tarefa que exigia, declara, o recurso à "investigação científica", apoiada por "ciências novas, que dão um valor inestimável a compreensão científica do fenômeno histórico". Dentre elas cita a antropo-sociologia de Gobineau, Lapouge e Ammon; a psicofisiologia de Ribot, Sergi, Langes, James; a psicologia coletiva de Le Bon, Sighele e Tarde; a ciência social de Le Play, Tourville e seus auxiliares.

Sua análise se orienta para a conclusão de sermos “povos de origem colonial e de civilização de transplante” e não dispormos “[já] no momento da Inde-

\footnotetext{
${ }^{21}$ Remeto ao capítulo 5 - Liberalismo, ideia exótica!, no já citado O charme da ciência e a sedução da objetividade, p. 295-366.
} 
pendência (...) de agentes eficazes de integração social e integração política”. Constatação que esclarece a ausência do elemento básico de integração social - a "solidariedade" - que ao superar a "solidariedade de clã" formaria laços sólidos entre os diversos elementos da população. Esse um dos argumentos de maior peso em sua análise e base da conclusão de que a sociedade se baseia em uma hierarquia estruturada na dependência em sentido vertical sem constituir vínculos de solidariedade no plano horizontal. A imensidão do território situado nos trópicos dispusera os grandes senhores de terras numa situação em que poucas situações os levaram a unirem esforços contra um inimigo comum. Prevalecera a independência entre os vários domínios rurais e neles o exercício da vontade soberana do senhor sobre todos os seus dependentes. Não havia nada além da "solidariedade do clã rural em torno do grande senhor de terras". Situação, a seu ver, de todo diversa à das populações europeias, marcadas em sua longa história, fosse pelas ameaças constantes de vizinhos premidos por necessidade de expansão de seus territórios ou então pelas "instituições de cooperação social das tradições do povo luso (...) festividades aldeãs, das ceifas, das vindimas," que aqui não haviam se aclimatado. ${ }^{22}$ Decorria dessa análise, ser "função política das populações do centro sul”:

Dar consistência, unidade, consciência comum a uma vasta massa social ainda em estado ganglionar, subdividida em quase duas dezenas de núcleos provinciais, inteiramente isolados entre si material e moralmente: - eis o primeiro objetivo.

Realizar, pela ação racional do Estado, o milagre de dar a essa nacionalidade em formação uma subconsciência jurídica, criando-lhe a medula da legalidade; os instintos viscerais da obediência à autoridade e à lei, aquilo que Ihering chama "o poder moral da ideia do estado"; - eis o segundo objetivo.

E insiste:

Quer dizer: pela instituição de um Estado centralizado, com um governo nacional poderoso, dominador, unitário, incontrastável, provido de capacidades bastantes para realizar, na

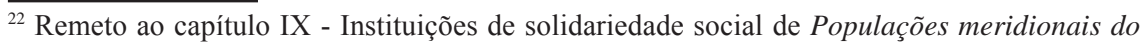
Brasil, op. cit., p. 155-164.
} 
sua plenitude, os seus dois grandes objetivos capitais: - a consolidação da nacionalidade e a organização da sua ordem legal (textos em itálico no original). ${ }^{23}$

No cerne da projeção da nação plenamente configurada se encontra uma teoria das elites, por ele designadas como "escol dirigente". A "grande obra de organização nacional” caberia como missão às "capacidades" das populações centro-meridionais - por seu "valor inestimável de virtudes pacíficas e ordeiras, instintos de brandura e moderação, horror do sangue e da luta”. Esta não poderia ser deixada às populações do norte (compreendo o nordeste atual) e o extremo-sul, por estarem elas “contaminadas” pela "lança do guerrilheiro ou o cangaço do jagunço”. A esse estudo seguiram-se, em curto espaço de tempo, vários outros em que confirmou suas ideias mestras e, em 1930, explicita seu projeto político com Problemas de política objetiva ${ }^{24}$ ao propor a "necessidade de organizar as classes produtoras do país”, de modo a, por sua vez, “organizar as fontes de opinião pública e de opinião democrática, torná-las mais amplas e mais autorizadas", apartando-as do "espírito faccioso dos partidos políticos”, de modo a tornarem "mais expressivas dos interesses coletivos e dos interesses econômicos".

Seu projeto se funda na formação dos “conselhos técnicos”, aos quais dedica quatro capítulos do livro nos quais expõe o que ocorria na Europa (Inglaterra, França, Itália, etc.) e esboça sugestões para o Brasil. A noção de "solidariedade” mantém-se como fundamento de seu projeto e sua formação se daria na própria atividade do trabalho, nesses conselhos de "caráter meramente profissional, sem objetivos de luta ou de conquista política", com a função de "colaboração de caráter técnico e profissional”. A proposta - baseada em experiências da França (comitês consultivos), Inglaterra (cabinet-secretariat) e Itália (gruppi de competenza) motivaria, em 1932, o convite para assessorar o ministro do Trabalho do governo de Getúlio Vargas, tarefa que desenvolveu até 1938 e lastreou a legislação sindical corporativista do Estado Novo. Expôs suas ideias em vários artigos publicados em 1938 no Jornal do Comércio, reunidos em 1938 no livro Problemas de direito corporativo. Neles apresenta em detalhes "o projeto de

\footnotetext{
${ }^{23} \mathrm{O}$ argumento e citações constam do último capítulo (XIX) às p. 285-287.

${ }^{24}$ VIANNA, Oliveira. Problemas de política objetiva. $3^{\text {a }}$ ed. Rio de Janeiro: Record/Fundação Oliveira Vianna/ Governo do Estado do Rio de Janeiro, 1974. $1^{\text {a }}$ ed. 1930.
} 
organização da Justiça do Trabalho", enviado à Câmara em 1935, antes, portanto, do golpe de novembro de 1938 que instaurou a ditadura do Estado Novo. ${ }^{25}$

Retrato do Brasil de Paulo Prado, publicado em 1927, vem a seguir. Da intenção de seu autor, diz Carlos Augusto Calil na Introdução da edição de $1998,{ }^{26}$ ter descoberto sua terra em viagem a Paris e na volta definido "um projeto e um programa": "investigar as origens da nacionalidade para embasar um orgulhoso nacionalismo, e provocar o surto radical de uma arte brasileira, que espanasse o pó acumulado de anos de conformismo e cultura de importação”. Paulo Prado, tal como Oliveira Vianna deu primazia às características físicas e climáticas do território e às populações que o colonizaram:

O encontro do europeu, ao sair da zona temperada, com a exuberância da natureza tão nuançada de força e graça, foi certamente a culminância de sua aventura (...) Colombo registra a impressão de deslumbramento diante do esplendor tropical... ${ }^{27}$

Entretanto, diria o autor páginas adiante:

O clima, o homem livre na solidão, o índio sensual, encorajavam e multiplicavam as uniões de pura animalidade. A impressão edênica que assaltava a imaginação dos recémchegados exaltava-se pelo encanto da nudez total das mulheres indígenas. ${ }^{28}$

Já no Î́ndice, os títulos dos capítulos dispõem a sequência de sua exposição: A luxúria, A cobiça, A tristeza, O romantismo, além de um post-scriptum no qual sugere uma imprecisa "Revolução". Imbuído da ideia de que "numa terra radiosa vive um povo triste”, Prado logo antecipa seus argumentos: “dois grandes impulsos (...) dominam a psicologia da descoberta e nunca foram geradores de alegria: a ambição do ouro e a sensualidade livre e infrene”.

A força dos trópicos, sua natureza exuberante e nuançada, “árvores de mil espécies, pássaros, bandos de papagaios” teriam encantado os descobridores que não se darem conta do quanto significava de obstáculo formidável à ocupação permanente. A miscigenação, fruto da luxúria desenfreada, e a cobiça, “na loucura do enriquecimento rápido” constituíam explícitas demonstrações de

\footnotetext{
${ }^{25}$ VIANNA, Oliveira. Problemas de direito corporativo. $2^{\mathrm{a}}$ ed. Brasília: Câmara dos Deputados, 1983. $1^{\text {a }}$ edição em 1938.

${ }^{26}$ CALIL, Carlos Augusto. Introdução a Retrato do Brasil de Paulo Prado. 9a ed. São Paulo: Companhia das Letras, 1997, p. 10-11.

${ }^{27}$ PRADO, Paulo. Retrato do Brasil, op. cit., p. 58.

${ }^{28}$ PRADO, Paulo. Retrato do Brasil, op. cit., p. 72.
} 
que faltara "a Portugal a verdadeira compreensão histórica e econômica da sua missão metropolitana. ${ }^{29}$ Como resultado, "a grande obra” dos conquistadores limitara-se à "criação e formação de um outro povo, a quem puderam legar a língua natal e as peculiaridades raciais da civilização portuguesa”. A mestiçagem se dera aos poucos: à sensualidade edênica do indígena somou-se "o negro" que, além do “elemento étnico” propiciara a promiscuidade do convívio na escravidão. "Tornou-se lendária a sedução da negra e da mulata para o colono português", diz. Como resultado, prevalecera "a filosofia da senzala, em maior ou menor escala latente nas profundezas inconfessáveis do caráter nacional” ${ }^{30}$

Ao introduzir a "tristeza”, decorrente da "luxúria” e da “cobiça”, Paulo Prado antecipa um argumento desenvolvido por Sérgio Buarque de Holanda na comparação entre a ação colonizadora portuguesa e a dos "peregrinos ingleses" aportados em terras da costa atlântica norte em 1620 a bordo do Mayflower e sua ética do trabalho. Disciplina religiosa e luta contra um clima duro formariam um "tipo moral predominante na história do país”, a despeito da escravidão posterior nas colônias mais ao sul. Já a "cobiça” e os "desvarios da preocupação erótica” restariam como "traços indeléveis no caráter brasileiro” e estender-seiam “até o domínio da inteligência, dos sentimentos”, produzindo "perturbações somáticas e psíquicas, acompanhadas de profunda fadiga”. Característica que, no decurso dos séculos, criara "uma raça triste”, tomada do "mal romântico" e de sua expressão cultural, o romantismo, e, inversamente ao que ocorrera nos países da Europa, onde essa expressão cultural fora moda e passara, no Brasil legara a "hipertrofia da imaginação e da sensibilidade", desequilíbrio que nos apartava "da positividade da vida moderna e das forças vivas e inteligentes que constituem a realidade social”. Parlamentarismo à inglesa de cunho liberal, ou a "journée des dupes” do Quinze de Novembro foram os resultados funestos desse desequilíbrio mental. ${ }^{31}$

O que esperar dessa população desestruturada em seu cerne? Ora, dirá Prado, “esgotadas as medidas da terapêutica corrente, é necessário recorrer à cirurgia”. Entre a guerra e a revolução, o autor se inclina para a última que não delineia de modo claro. Diz simplesmente não ser "uma simples revolta de soldados”, mas que virá de "mais longe e de mais fundo”. Em projeção trágica, a pers-

\footnotetext{
${ }^{29}$ PRADO, Paulo. Retrato do Brasil, op. cit., p. 58, 91, 94.

${ }^{30}$ PRADO, Paulo. Retrato do Brasil, op. cit., p. 126, 190-195.

${ }^{31}$ PRADO, Paulo. Retrato do Brasil, op. cit., p. 131-133, 139-140, 164-165, 181.
} 
pectiva de catástrofe não se limita à situação brasileira; estende-se aos “países de velha civilização" em conflito entre "os mais variados ismos: capitalismo, comunismo, fordismo". Como mensagem, deixa somente a projeção otimista de que o revolucionário é construtor de uma nova ordem. Qual?

Alguns anos depois, em 1933, Gilberto Freyre publicava Casa-grande \& senzala, livro que até 1980 conheceria 20 edições. No título do primeiro capítulo desenha-se o percurso de sua exposição - Características da colonização portuguesa no Brasil: formação de uma sociedade agrária, escravocrata e híbrida. Características que define logo nos parágrafos iniciais:

Formou-se na América tropical uma sociedade agrária na estrutura, escravocrata na técnica de exploração econômica, híbrida de índio - e mais tarde de negro - na composição. Sociedade que se desenvolveria defendida menos pela consciência de raça, quase nenhuma no português cosmopolita e plástico, do que pelo exclusivismo religioso (...) Menos pela ação oficial do que pelo braço e espada do particular (...) as grandes famílias proprietárias e autônomas: senhores de engenho (...) Bem diversos dos criollos ricos e dos bacharéis letrados da América espanhola... ${ }^{32}$

Tal como Oliveira Vianna e Paulo Prado, Freyre afirmou a "grande influência do clima amolecedor" sobre o Português em terras africanas e americanas, e o moldou como "povo indefinido entre a Europa e a África". Posição também adotada em Raízes do Brasil por Sérgio Buarque de Holanda. Indefinição que conferira ao colonizador plasticidade e lhe assegurara em boa parte o sucesso de fixação permanente e civilizacional em territórios tropicais que outras etnias não haviam obtido. "População indecisa no meio dos dois bandos contendores [nazarenos e maometanos] meia cristã, meia sarracena, e que em ambos contava parentes, amigos, simpatias de crenças ou de costumes, na opinião de Alexandre Herculano, citado por Freyre. Traz também, em apoio dessa convivência harmoniosa, a opinião de Herman Keyserling sobre a "união profunda" em que viviam "figuras com ar escandinavo e negróides" em terras portuguesas. Mobilidade, confirmada pela presença em terras distantes da Ásia, África e América; miscibilidade, inigualável e inexcedível; aclimatabilidade fácil em situações na própria terra natal e experiências anteriores, seriam as características do português. ${ }^{33}$ Esses elementos formativos da população de Portugal são

\footnotetext{
${ }^{32}$ FREYRE, Gilberto. Casa-grande \& senzala. Formação da família brasileira sob o regime da economia patriarcal. São Paulo: Círculo do Livro, s.d., p. 43.

${ }^{33}$ Encontramos referência crítica a Oliveira Vianna em relação aos argumentos de Raça e assimi-
} 
retomados e detalhados no capítulo III - “O colonizador português: antecedentes e predisposições”, quando volta a citar Oliveira Vianna de quem discorda em relação a questão racial. ${ }^{34}$

Os traços do caráter da "figura do colonizador" são longamente detalhados no capítulo III - “O colonizador português: antecedentes e predisposições”. Diferenças e oposições são registradas na comparação entre o castelhano, "por natureza gótico, vertical (...) grecóide (...) alongamento mórbido (...) 'ferrea austeridad' exagerada crueldade”, e o português, cuja “deformação” se dera "no sentido horizontal (...) arredondamento (...) exagero da carne em luxúria (...) realismo econômico (...) materialização bruta de todos os valores da vida (...) erotismo rasteiro”. A despeito dessas características em tese negativas, o português se sobressaíra ao se antecipar aos europeus no "burguesismo". No arrolamento dos contrastes, Freyre conota negativamente o aristocratismo castelhano, porém, de forma ambígua, afirma ter o burguesismo do português se arrefecido em terras da América e que, em movimento de retorno, processara "aristocraticamente a colonização do Brasil”, em particular no "norte (...) aristocrático, 'patriarcal, escravocrata”, onde o colonizador “fundou a maior civilização moderna nos trópicos”. Apoiado no sistema político das sesmarias, Freyre classificou a colonização de ter se realizado em "condições francamente feudais”, e propiciado ao todo poderoso senhor patriarcal subjugar até a igreja. "No Brasil,” diz, “a catedral ou a igreja mais poderosa que o próprio rei seria substituída pela casa-grande de engenho". Confirma sua observação em termos arquitetônicos, já que na comparação entre a edificação religiosa, a capela, seria sempre menor e mais baixa do que a casa-grande sobranceira. ${ }^{35}$

Apesar de apontar o "choque das duas culturas, a europeia e a ameríndia”, e o "contato dissolvente" do europeu sobre a população nativa, Freyre foi o autor que explicitamente valorizou a contribuição de cada "raça” e conferiu valor positivo à miscigenação:

Híbrida desde o início, a sociedade brasileira é de todas da América a que se constituiu mais harmoniosamente quanto às relações de raça; dentro de um ambiente de quase reci-

lação (1932) dada a alegada parcialidade na escolha de autores especializados em climatologia e antropogeografia, op. cit., p. 49.

34 FREYRE, Gilberto. Casa-grande \& senzala, op. cit., p. 228-232.

${ }^{35}$ FREYE, Gilberto. Casa-grande \& senzala, op. cit., p. 220-224. 
procidade cultural que resultou no máximo de aproveitamento dos valores e experiências dos povos atrasados pelo adiantado; (...) da do conquistador com a do conquistado. ${ }^{36}$

Talvez até por recorrer em parte a documentos usados por Paulo Prado registros de jesuítas e do Santo Ofício -, Freyre enfatiza, no capítulo II dedicado a apresentar "O indígena na formação da família brasileira”, o apelo sensual da “índia nua”, perante a qual até “os próprios padres da Companhia [de Jesus] precisavam [de] cuidado, senão atolavam o pé em carne”. Presença importante a da "mulher gentia (...) não só por constituir “a base física da família brasileira, (...) mas [por ser] valioso elemento de cultura, pelo menos material”. Por meio delas, preservara-se em parte a cultura dos nativos. ${ }^{37}$

Seriam, entretanto, dedicados ao africano e seus descendentes em terras brasileiras dois capítulos do livro: IV e V - "O escravo negro na vida sexual e de família do brasileiro". Também neles, Freyre estabelece a comparação entre o indígena nativo e o africano: o caráter introvertido do indígena e o tipo extrovertido do negro. Embora afirme não desejar se alongar em "critério de tipos psicológicos”, traça o caráter da “população negróide baiana - alegre, expansiva, sociável, loquaz”, e o das "populações indígenas - tristonhas, caladas, sonsas e até sorumbáticas”. Características que, por sua vez, teriam dado ao negro “disposição psíquica e de adaptação talvez biológica ao clima” e a condição de “maior e mais plástico colaborador do branco na obra de colonização agrária”, inclusive na dieta e regime alimentar. ${ }^{38}$ Freyre entra em polêmica direta com os que, a seu ver, buscavam atribuir "à inferioridade do negro (que seria congênita) a realizações e iniciativas de ordem intelectual e técnica”. Cita em apoio de seus argumentos vários estudos de pesquisadores estadunidenses, com os quais polemiza ou concorda, dentre os quais o sempre citado mestre Frans Boas. Com argumentos fortes enfariza que "o Brasil não se limitou a recolher da África a lama de gente preta que fecundou os canaviais e cafezais (...). Vieram-lhe da África 'donas de casa' para seus colonos sem mulher branca; técnicos para as minas; artífices em ferro; negros entendidos na criação de gado e na indústria pastoril; comerciantes de panos e sabão; mestres, sacerdotes e tiradores de reza maometanos." ${ }^{39}$ Discorda dos que atribuem a "defeito da raça africana,

\footnotetext{
${ }^{36}$ FREYE, Gilberto. Casa-grande \& senzala, op. cit., p. 127.

${ }^{37}$ FREYE, Gilberto. Casa-grande \& senzala, op. cit., p. 129.

${ }^{38}$ FREYE, Gilberto. Casa-grande \& senzala, op. cit., p. 312-313.

${ }^{39}$ FREYE, Gilberto. Casa-grande \& senzala, op. cit., p. 330-331.
} 
comunicado ao brasileiro, o erotismo, a luxúria, a depravação sexual”. E recorre novamente a estudiosos da sexualidade humana, como Havelock Ellis, para afirmar terem os negros mais moderação no apetite sexual do que os europeus e de até necessitarem de danças afrodisíacas para se excitarem. Depõe, assim, no regime de escravidão o que de patogênico se atribuía ao africano. ${ }^{40}$

No desenho desse amplo painel da colonização portuguesa, Freyre avança na primeira metade do século XIX, quando o Brasil, já independente, investe em estradas de ferro e rompe o círculo de "isolamento árabe em que viviam as antigas sinhás-moças (...) nas casas de engenho”. Vida limitada à “alcova, camarinha, bem no centro da casa, rodeada de quartos de pessoas mais velhas. Mais uma prisão do que aposento de gente livre”, conclui. Aposentos rodeados, por sua vez, de "grossas paredes, (...) verdadeiros ralos de convento em que se guardavam as sinhás-moças, [onde] vinham colhê-las verdes o casamento; aos treze e aos quinze anos”. ${ }^{41}$ Não há, entretanto, sequer esboço de projeto política em Casa-grande \& senzala.

O mesmo acontece logo em seguida em Sobrados e mucambos, ${ }^{42}$ de 1936 , livro no qual Freyre acompanhou a nova relação de poder que, entretanto, não modificara a situação, o poder "dos senhores, o dos brancos, o dos homens." Cm certeza, para além do relaxamento da clausura das moças, vários costumes se modificaram. As posturas municipais no início do século XIX [mais precisamente após lei imperial de 1828] passaram a restringir nas cidades "a liberdade dos particulares”, dentre elas a prática “dos senhores dos sobrados surrarem seus escravos depois que o sino da igreja batesse solenemente nove horas da noite”. Atuaram, sobretudo, no uso disciplinado dos espaços de uso público, ruas e praças, vedados os jardins aos "negros de pé no chão, caixeiros de chinelos e mesmo aos portugueses de tamancos”, obrigaram os proprietários a alinharem suas casas nos passeios, a eliminarem as biqueiras que desaguavam sobre a rua, a retirarem das ruas os animais de criação. ${ }^{43}$

Em adendos sucessivos ao Prefácio da $1^{\text {a }}$ edição de Casa-grande \& senzala [1936-1949-1961], Freyre respondeu as críticas, dentre as quais a de João Ribeiro que dele disse "pouco concluir”, e a quem responde ter sido exatamente essa sua intenção - interpretar e esclarecer o material reunido. Material que

\footnotetext{
${ }^{40}$ FREYE, Gilberto. Casa-grande \& senzala, op. cit., p. 337-342.

${ }^{41}$ FREYE, Gilberto. Casa-grande \& senzala, op. cit., p. 358-360.

${ }^{42}$ FREYRE, Gilberto. Sobrados e mucambos. Rio de Janeiro/São Paulo: Record, 1996. ${ }^{\text {a }}$ ed. 1936.

${ }^{43}$ FREYRE, Gilberto. Sobrados e mucambos, op. cit., p. XLIII-XLVII.
} 
em sua opção "Sugere mais do afirma. Revela mais do que sentencia". Nega ter recuado frente "a responsabilidade intelectual”; por opção "buscara a maior objetividade possível, de método e de técnica.” Dirige reticências aos autores de “interpretações marxistas ou explicações behavioristas ou paretistas” e conclui: "É tempo de procurarmos ver na formação brasileira a série de desajustamentos profundos, ao lado dos ajustamentos e dos equilíbrios (...) desembaraçados de conclusão interessada" ${ }^{44}$

Se Freyre afirma nos dois primeiros e extensos volumes da trilogia incompleta uma intenção desinteressada, o curto Manifesto regionalista de 1926 toma direção francamente oposta. Apresento o Manifesto por último por ter sido publicado somente em $1955 .{ }^{45}$ Da demora a ser dado a público, Freyre diria ter "sumido ao lado do Modernismo do Rio e do de São Paulo, seus parentes ricos e aparecidos um pouco antes dele". Faltara-lhe, afirma, "propaganda e divulgação na imprensa metropolitana, então indiferente, senão hostil, ao que fosse ou viesse de Província”. Embora controversa a data, o Manifesto nos interessa aqui por Freyre situá-lo no período em que se multiplicaram os manifestos e projetos políticos com a intenção de transformar a sociedade brasileira, projetos que foram muito além das manifestações dos ativos organizadores da Semana de 22 em São Paulo. ${ }^{46}$ Embora Freyre fale de “um grupo apolítico” reunido “em volta da mesa de chá com sequilhos e doces tradicionais da região”, ocasiões nas quais se discutiam "problemas do Nordeste", o Manifesto traz uma clara proposta de reorganização política do país. O que denomina de "nova espécie de regionalismo" contém uma proposta que busca a adesão de outras partes do Brasil e a ela dar "o sentido organicamente brasileiro e até americano". Sua proposta de sentido orgânico pressupõe substituir o "estadualismo" por um "novo e flexível sistema de regiões, mais importantes do que os Estados". As regiões se completariam "ativa e criadoramente numa verdadeira organização nacional”, em tudo oposta ao que, na mesma esteira de Oliveira Vianna e Paulo

\footnotetext{
${ }^{44}$ FREYRE, Gilberto. Sobrados e mucambos, op. cit., p. L-LI.

${ }^{45}$ FREYE, Gilberto. Manifesto regionalista de 1926. Brasília: Ministério da Educação e Cultura, 1955.

${ }^{46}$ Além da festejada e muito estudada Semana de Arte Moderna de 22 em São Paulo lembro a coletânea organizada por CARDOSO, Vicente Licínio. À margem da história da República, em dois volumes, editada em 1924, com textos de vários autores considerados “conservadores”, entre os quais se encontra a primeira versão de O idealismo da Constituição de Oliveira Vianna. Reeditada em 1981 pela EdUnB.
} 
Prado, denominou de importação de ideias e instituições em nada adequadas a sociedade brasileira. Em suas palavras, o que desejava inspirar era:

Uma nova organização em que as vestes em que anda metida a República - roupas feitas, roupagens exóticas, veludos para frios, peles para Gelos que não existem aqui - sejam substituídas não por outras roupas feitas por modesta estrangeira mas por vestido ou simplesmente túnica costurada pachorrentamente em casa: aos poucos e sob medida. ${ }^{47}$

Era opinião de Freyre e seus amigos a necessária adoção do bom senso para se evitar o que acontecia no país há mais de um século: “desde que é nação, as estrangeirices que lhe tem sido impostas, sem nenhum respeito pelas peculiaridades e desigualdades da sua configuração física e social". Aos homens públicos do Império atribuiu terem-se se dobrado ao "imperialismo da Corte afrancesada ou anglicizada”, atitude persistente quando as novas instituições se espelharam na "República ianquizada", modelo para um território que, a seu ver, ainda não estava preparado para se organizar institucionalmente em Estados. Considera ser a "realidade regional” a condizente com "a realidade brasileira”. Sua referência a Sílvio Romero e a noção de "regiões naturais às quais se sobrepuseram regiões sociais” estabelece vínculo entre meio ambiente e sociedade de modo que essa constelação de regiões apontava a forma pela qual o Brasil devia “ser administrado, (...) ser estudado: Regionalmente”. Em crítica implícita à noção de região adotada por Oliveira Vianna, seu foco dirige-se, sobretudo, à preponderância dada pelo autor fluminense ao centro-sul em detrimento do nordeste. Para Freyre, a região nordeste constituía a matriz da "riqueza de tradições ilustres (...) depois impostas aos outros brasileiros”. Imposta, sublinha, não tanto "pela superioridade econômica do açúcar" e sim "pela sedução moral e pela fascinação estética dos mesmos valores”. Sua sentença é clara: por ser "a doce aristocracia de maneiras e gostos, de modos de viver e de sentir" bem anterior ao "café de São Paulo - o Nordeste” teria o direito de considerar-se "uma região que já grandemente contribuiu para dar à cultura ou à civilização brasileira autenticidade e originalidade e não apenas doçura e tempero". ${ }^{48}$

$\mathrm{O}$ texto segue com o elogio às velhas ruas estreitas do Nordeste e seus nomes saborosamente regionais, à honesta arquitetura burguesa do Recife com reminiscências orientais e africanas e em defesa dos valores plebeus e não apenas

\footnotetext{
${ }^{47}$ FREYE, Gilberto. Manifesto regionalista de 1926, op. cit., p. 16.

${ }^{48}$ FREYE, Gilberto. Manifesto regionalista de 1926, op. cit., p. 20.
} 
aqueles elegantes e eruditos, da reabilitação dos valores culinários em boa parte herança do forno e fogão de Portugal. "Pois o Brasil é isto: combinação, fusão, mistura”, proclama, e não o “mau cosmopolitismo e o falso modernismo. É todo o conjunto da cultura regional que precisa ser defendido e desenvolvido" ${ }^{49}$

Sérgio Buarque de Holanda, ativo participante da Semana de 22, embora tenha se distanciado da maioria dos colegas que com ele dividiram a cena, publicava seu primeiro ensaio historiográfico, no mesmo ano de Sobrados e mucambos. Raízes do Brasil $^{50}$ constitui o volume que dá início à Coleção Documentos Brasileiros dirigida pelo próprio Gilberto Freyre, na casa editora José Olympio, a mesma que editou por muitos anos, com exclusividade, os livros de Oliveira Vianna. ${ }^{51}$ Embora defendam posições divergentes sobre a projeção do Brasil futuro, Freyre elogia o trabalho de Buarque de Holanda e reconhece que nele há uma variedade de material ainda virgem no movimento intelectual que agitava o país. Freyre também tece comentários positivos ao editor José Olympio pela iniciativa de "uma colleção planejada e organizada com o maior escrúpulo e com todo o vagar". Fariam parte da coleção livros de memória, biografias documentadas, narrativas de viagens e "estudos sobre as nossas populações atuais”. Da lista de autores previstos consta, ao lado de Affonso Arinos de Mello Franco, do médico higienista dr. Paula Souza e do engenheiro Ulhôa Cintra, Sylvio Rabello e tantos outros, o nome de Oliveira Vianna com destaque. ${ }^{52}$

Editado em meio ao "clima” de debates e da multiplicidade de projetos políticos das décadas de 1920 e 1930, Raízes do Brasil de Buarque de Holanda traz uma hipótese central expressa já no primeiro parágrafo:

\footnotetext{
${ }^{49}$ FREYE, Gilberto. Manifesto regionalista de 1926, p. 21-54.

${ }^{50}$ HOLANDA, Sérgio Buarque. Raízes do Brasil. Rio de Janeiro: Livraria José Olympio Editora, 1936. As referências são da $1^{\text {a }}(1933)$ e da $5^{\text {a }}$ (1969) edições.

${ }^{51} \mathrm{Na} 4{ }^{\mathrm{a}}$ edição de Raça e assimilação de 1959, livro da Coleção Documentos Brasileiros, em nota abaixo da lista de livros de Vianna publicados por essa editora vem escrito: "Todas as obras de Oliveira Vianna serão publicadas pela Livraria José Olympio Editora com exclusividade”.

${ }^{52}$ Cf. p.VI-IX da apresentação de Gilberto Freyre à $1^{\text {a }}$ edição de Raízes do Brasil de Sérgio Buarque de Holanda.
} 
Trazendo de países distantes as nossas formas de vida, nossas instituições e nossa visão do mundo e timbrando em manter tudo isso em um ambiente muitas vezes desfavorável e hostil, somos ainda uns desterrados em nossa terra. ${ }^{53}$

Nos vários capítulos do livro reaparece a decorrência funesta desse transplante, mais detalhadamente retomado no último capítulo "Nossa revolução":

Escapa-nos a verdade de que não são as leis escritas e fabricadas pelos jurisconsultos, ou o cumprimento fiel dessas leis, as mais legitimas garantias de felicidade para os povos e de estabilidade para as nações. (...) Essa opinião enganosa tomou vulto depois de incentivada a crença no mytho do progresso, com o êxito do comtismo, do spencerismo, do marxismo, e de tantas ideologias semelhantes, de que foi singularmente fertil o seculo que antecedeu o nosso. ${ }^{54}$

Seus argumentos críticos aos que acreditaram ser factível "preceder o mundo das formas vivas do mundo das fórmulas e dos conceitos” se estendem a "todas as revoluções modernas” por fundamentarem "motivos em concepções abstractas como os famosos Direitos do Homem”. Argumentos que ganham intensidade ao serem noções adotadas pelos “povos da nossa America” entre os quais prevalecia “o predominio do elemento emotivo sobre o racional” oposto ao "liberalismo”, “uma theoria essencialmente neutra, despida de emocionalismo e enquadrada em formulas”, do “personalismo” sobre a “despersonalização democrática”. Argumentos que levam a uma só conclusão: “a adopção das formulas democraticas no Brasil e em outros paizes do continente, (...) resultou simplesmente de um mal-entendido”. ${ }^{5}$

O argumento do descompasso entre “a norma de nossa conduta” modelada pela que orienta a vida “dos países mais cultos” se mantém nas edições subsequentes e ganha força com a imagem do transplante de preceitos e ideias:

\footnotetext{
${ }^{53}$ HOLANDA, Sérgio Buarque. Raízes do Brasil, op. cit., p. 3 (1933). Na edição de 1969, a mesma afirmação é complementada pela frase que a antecede: “A tentativa de implantação da cultura europeia em extenso território, dotado de condições naturais, se não adversas, largamente estranhas à sua tradição milenar, é, nas origens da sociedade brasileira, o fato dominante e mais rico de consequências. Trazendo de países distantes nossas formas de convívio, nossas instituições, nossas ideias, e timbrando em manter tudo isso em ambiente muitas vezes desfavorável e hostil, somos ainda hoje uns desterrados em nossa terra”.

${ }^{54}$ HOLANDA, Sérgio Buarque. Raízes do Brasil, op. cit., p. 146 (1936).

${ }^{55}$ HOLANDA, Sérgio Buarque. Raízes do Brasil, op. cit., p. 146-155 (1936).
} 
Trouxemos de terras estranhas um sistema complexo e acabado de preceitos, sem saber até que ponto se ajusta às condições da vida brasileira. (...) Na verdade a ideologia impessoal do liberalismo democrático jamais se naturalizou entre nós. (...) A democracia no Brasil foi sempre um lamentável mal-entendido. Uma aristocracia rural e semifeudal importou-a e tratou de acomodá-la onde fosse possível. ${ }^{56}$

Por partirem quase sempre de cima para baixo, afirma, "os movimentos reformadores foram de inspiração intelectual” e "a grande massa do povo recebeu-as com displicência, ou hostilidade..." ${ }^{57}$ Em posição semelhante à de Oliveira Vianna, para quem as leis, quando não adequadas a cada país, seriam ineficientes, Buarque de Holanda também cita Alberto Torres:

A política é, de alto a baixo, um mechanismo alheio á sociedade, perturbador de sua ordem, contrario ao seu progresso; governos, partidos e politicos succedem-se e alternam-se, levantando e combatendo desordens, creando e destruindo coisas inuteis e embaraçosas. ${ }^{58}$

Para Buarque de Holanda, a questão de fundo - a separação "entre a nação e sua vida política” - decorria da "alheação da realidade”, já que a intelectualidade mantinha atitude de "secreto horror á nossa realidade" e se recusasse sistematicamente a ver "a feia realidade brasileira”. Sua atitude implicava em um "voluntário alheamento ao mundo circunstante”. ${ }^{59}$ Nessas circunstâncias, o resultado não poderia ser outro:

As Constituições feitas para não serem cumpridas, as leis existentes para serem violadas, tudo em proveito de indivíduos e oligarquias ... ${ }^{60}$

O brasileiro navegava na herança dos pais ibéricos constitutiva da distância entre o intelectual e a massa em um movimento em que a intelectualidade fabricava "uma realidade artificiosa e livresca" e a difundia para a população. Em seu livro, tal como em Casa-grande \& senzala de Freyre, a sequência dos capítulos expõe já no índice o eixo dos argumentos que desenvolverá desde as

\footnotetext{
${ }^{56}$ HOLANDA, Sérgio Buarque. Raízes do Brasil, op. cit., p. 118-119 (1969).

${ }^{57}$ HOLANDA, Sérgio Buarque. Raízes do Brasil, op. cit., p. 122 e 123 (1936); p. 119 (1969).

${ }^{58}$ HOLANDA, Sérgio Buarque. Raízes do Brasil, op. cit., p. 144-145 (1936). Não consta da edição de 1969.

${ }^{59}$ HOLANDA, Sérgio Buarque. Raízes do Brasil, op. cit., p. 123 (1969)

${ }^{60}$ HOLANDA, Sérgio Buarque. Raízes do Brasil, op. cit., p. 146 (1936); p. 133 e 137 (1969).
} 
páginas iniciais de "Fronteiras da Europa” até as derradeiras páginas de "Nossa revolução", passando pela "Herança rural” e pelo "Homem cordial”.

Tal como Paulo Prado e Gilberto Freyre, Buarque de Holanda dirige o foco para o colonizador, nascido na península Ibérica e como eles, o situa em “uma zona fronteiriça, de transição, menos carregada (...) desses europeísmos que, não obstante mantêm como um patrimônio necessário". Nas condições específicas dessa "região indecisa" constituíam-se "as formas de vida social." Segue a trilha de Paulo Prado ao atribuir a características do colonizador, "não a uma força exterior”, mas em especial, “à cultura da personalidade (...) a singular tibieza das formas de organização, de todas as associações que impliquem solidariedade e ordenação desses povos”. Surge também em seus argumentos a noção de "solidariedade”, noção base das análises de Oliveira Vianna, mas, ao contrário deste, considera "a falta de coesão em nossa vida social” não uma característica adquirida no solo tropical da grande propriedade rural, mas um traço de personalidade herdado dos pais fundadores, um pecado de origem. ${ }^{61}$

Deles os brasileiros carregavam o legado de uma série de características apresentadas como carências. Além da "reduzida capacidade de organização social”, ou a solidariedade reduzida ao círculo doméstico e de amigos (posição semelhante à de Oliveira Vianna), possuíamos traços de personalidade negativos, tais como, “a obediência cega” paralela e complementar à "vontade de mandar”, um "natural inquieto e desordenado" redundando em falta de disciplina e no "tipo aventureiro" oposto a "ética do trabalho", a grande força impulsionadora da Inglaterra protestante na Era Vitoriana. A lista de carências ou traços de personalidade negativos prossegue com a pouca criatividade e persistência das "concepções rotineiras, sem progressos técnicos que elevassem o nível de produção” na grande lavoura de exportação, agravada pelo meio tropical; com "a ausência completa de qualquer orgulho de raça” por ser o português um povo de mestiços já na metrópole; com o “exíguo sentimento de distância entre os dominadores e a massa trabalhadores de homens de cor” em relações que penetravam "sinuosamente o recesso doméstico"; e com a "ausência de esforço sério de cooperação”, inclusive na organização dos ofícios. Buarque de Holanda se une ao coro da "influência dos negros, sobretudo como escravos" na definição de traço negativo de nossa índole - "uma suavidade dengosa e açucarada

\footnotetext{
${ }^{61}$ Remeto ao capítulo 2, que leva esse título, no já citado $O$ charme da ciência e a sedução da objetividade, p. 101 e seguintes.
} 
invade, desde cedo, todas as esferas da vida colonial”, penetra profundamente a sociedade e dá lugar à "moral das senzalas” [entre aspas no original], uma "ética de fundo emotivo" característica do "homem cordial”, inserida em todas as dimensões da sociedade - "na administração, na economia e nas crenças religiosas dos homens do tempo". ${ }^{62}$

Em sua interpretação da história do Brasil, Buarque de Holanda elabora uma representação bastante negativa da herança legada pelos pais fundadores, já que, no longo decorrer de séculos de colonização, a "mentalidade da casagrande invadira as cidades e conquistara todas as profissões, sem exclusão das mais humildes”; estendera-se e invadira o espaço público, criara a distorção na qual a "entidade privada precede sempre a entidade pública”. A própria configuração do espaço urbanizado se dera com desleixo, evidente no traçado de nossas cidades em nítido contraste ao rígido traçado ortogonal das cidades fundadas pelo colonizador espanhol, fruto do esforço determinado de conquista do território. Na colônia portuguesa, a fundação de cidades se limitara, quase exclusivamente, ao litoral e dera lugar à evidência física do “desequilíbrio entre o esplendor rural e a miséria urbana”. ${ }^{63}$ Em termos humanos, o resultado fora o "homem cordial”, o oposto do cidadão, para quem a noção abstrata, impessoal de cidade se via afogada pelos "laços de afeto e de sangue”. Homem formado na cordialidade estranha a todo formalismo e convenção social, avesso ao caráter coercitivo das normas de civilidade; em suma, a quem faltavam "boas maneiras e civilidade”. Nem civilidade, nem compreensão da noção de cidadania. Sua personalidade mostrava-se avessa a qualquer sistema exigente e disciplinador do pensamento, e se moldara pelo "um amor pronunciado pelas formas fixas e pelas leis genéricas que circunscrevem a realidade complexa e difícil dentro do âmbito dos nossos desejos". ${ }^{4}$

Buarque de Holanda se inclui no pronome "nós”, e a esse coletivo atribui se deixar levar pelo "prestígio da palavra escrita, da frase lapidar, do pensamento

\footnotetext{
${ }^{62}$ Buarque de Holanda cita Paulo Prado em apoio de seus argumentos sobre a "influência dos escravos”. As carências listadas se dispõem ao longo de dois capítulos de Raízes do Brasil, op. cit., em particular (I - Fronteiras da Europa e II - Trabalho e aventura. A referência a Max Weber e às características do "espírito protestante" em contraste com as nações católicas, avessas a ética do trabalho, constam de longa nota do capítulo VI - Novos tempos, p. 114.

${ }^{63}$ Argumentos desenvolvidos nos capítulos 3 - O passado agrário e 4 - O passado agrário (continuação) renomeados os título Herança rural e O semeador e o ladrilhador (1969). In: HOLANDA, Raízes do Brasil, op. cit.

${ }^{64}$ Argumento desenvolvido nos capítulos 3 e 4 de Raízes do Brasil, op. cit.
} 
inflexível,... à colaboração, ao esforço... a certa dependência e abdicação da personalidade”. Esse "nós” se deixava encantar por “essas construções de inteligência [que] representam um repouso para a imaginação, comparável à exigência de regularidade a que o compasso musical convida o corpo do dançarino”. O desleixo atuante na formação das cidades desliza para o plano do pensamento e da expressão cultural e justifica a fácil adesão ao "positivismo", "às definições irresistíveis e imperativas do sistema de Comte”, ao poder milagroso das ideias. Forma de "evasão da realidade” que coexistia com outras crenças, como o liberalismo democrático que, afirma, "jamais se naturalizou entre nós”. Convivera também com o romantismo que, apartado do "convencionalismo clássico", se fixara "no pessoal e no instintivo", alastrara-se entre nós, mal acordados para a vida de nação independente, na forma de "uma sensibilidade feminina, deliquescente, linfática”, criara "um mundo fora do mundo (...) o horror a nossa realidade cotidiana (...) o voluntário alheamento do mundo circunstante”. Seu argumento desenha essa inconsistência íntima de nosso pensamento, capaz somente de fabricar "uma realidade artificiosa e livresca": o modelo inglês de dois partidos definira as instituições políticas do Império tal como "a miragem da alfabetização do povo" levara à República.

Esses traços sombrios desenham a imagem do homem brasileiro (ou população brasileira) preso às amarras da má formação e, contudo, já vivenciando a lenta revolução instaurada pelo rompimento do primeiro elo da cadeia - a supressão do regime de trabalho escravo e a instauração das instituições republicanas, embora a elas impute, retomo sua afirmação, ter destruído “o poderoso esteio rural, que fazia a força do regime descahido, sem lograr substituil-o por nada de novo”. Há em Buarque de Holanda evidente projeção positiva do deslocamento do poder do ambiente rural para o urbano no que denominou de "uma revolução lenta, mas segura e concertada", projetada no "lento cataclismo (...) do aniquilamento das raízes ibéricas de nossa cultura”. A projeção desejada configurava a "urbanização contínua, progressiva, avassaladora", a "dissolução lenta, irrevogável das sobrevivências arcaicas (...) revogada a velha ordem colonial e patriarcal”. ${ }^{65}$

${ }^{65}$ HOLANDA, Sérgio Buarque. Raízes do Brasil, op. cit., cap. 7 - Nossa revolução, p. 135171(1936), p.126-142 (1969). 


\section{A utopia entre projetos e projeções}

A despeito dos fundamentos teóricos diferenciados e até divergentes, há nesses quatro autores escolhidos a base comum do tripé conceitual - o meio ambiente, as características étnicas da população e o percurso histórico desde os primeiros colonizadores. Todos também partem do pressuposto sobre qual se desenvolve a argumentação - a distância entre ideias e instituições e a sociedade; ideias trazidas de terras estranhas pelos pais fundadores, primeiro; importadas em seguida, quando, já livres da condição de colônia, se dera a adesão pouco refletida a modelos institucionais vigentes em outras nações, moldadas pelo caráter de outros povos, aqui simples miragens projetivas inoperantes, pela ausência do cidadão, sua base e elemento ativo. Há diálogo e discordâncias profundas entre eles; observações remetidas a posições divergentes: Oliveira Vianna coloca a possibilidade de seu projeto político em um Estado centralizado e autoritário capaz de moldar o cidadão sobre a base solidária do sindicato corporativo e da escola; Freyre projeta um Brasil harmonioso, orgânico, pois unido por regiões formadas por suas características geográficas e culturais; Buarque de Holanda deposita sua projeção de civilidade e de cidadania na urbanização progressiva e avassaladora e no Estado não despótico, mas sediado na pujança e compostura, na grandeza e solicitude.

Embora seus projetos tenham como foco e objetivo a figura ausente do cidadão, seus autores divergem e as discordâncias passam por concepções diferenciadas da sociedade desejada e fortemente alicerçadas em disputas sobre a importância relativa das regiões - Casa-grande \& senzala e o Manifesto regionalista de 1926 de Freyre reivindicam para o nordeste a matriz da cultura brasileira, formada em tempos coloniais, fechada a elementos estrangeiros. Esses dois textos de Freyre podem ser interpretados como se opondo a Oliveira Vianna que, na década de 1920, localiza o eixo político-econômico e social capaz de oferecer base segura a seu projeto na "escol dirigente" do atual Sudeste (em suas palavras as populações fluminenses, paulistas e mineiras) e localiza em terras das Minas Gerais os verdadeiros valores morais do "pater-familias”. Fincava na vocação rural do brasileiro o fundamento da "nossa psicologia nacional”: "O instinto urbano não está na sua índole; nem as maneiras e hábitos urbanos”. Regiões contrastantes em sua formação - o Nordeste açucareiro da grande propriedade agrícola formado ainda nos tempos da escravidão, idealizado por Freyre, e o pequeno fazendeiro de origem plebeia, idealizado na figura do patrício da Roma republicana, contrastando com os nobres senhores de terras de 
Pernambuco e São Paulo coloniais. Oliveira Vianna aposta nos valores e virtudes das populações rurais trazidas pelos "campônios do Douro", e Gilberto Freyre deposita na matriz nordestina da doce cultura da casa-grande suas projeções da nacionalidade. Olhares voltados para o interior do país e nele buscando as verdadeiras bases da nacionalidade.

Com eles concorda Buarque de Holanda ao exigir o abandono do olhar fixo em países estrangeiros e o reconhecimento da sociedade em que vivem. A eles se contrapõe, contudo, ao projetar, na urbanização aberta, a base da possível "revolução vertical”, capaz de trazer à tona elementos submersos nessa sociedade "mal formada desde suas raízes”, capaz de proceder ao "aniquilamento das raízes ibéricas de nossa cultura”. Posição explícita e radicalmente diversa de Oliveira Vianna e seus elogios ao patriciado rural formado "de elementos arianos”. Essa projeção é criticada por Buarque de Holanda que lhe imputa não compreender a imbricação insidiosa entre iberismo e agrarismo, e a necessidade da erradicação dos dois. Opunha-se também a Freyre por, ao contrário deste, apostar na ação benéfica do desaparecimento das formas tradicionais já anunciadas desde a decadência da lavoura do açúcar. Dirigia seu olhar para as cidades em projeto sem reminiscências a serem resguardadas. Seu projeto político aposta na erradicação da “cultura ainda largamente ibérica” e no legado rural da colonização; aposta na urbanização e na cidade como lócus privilegiado da formação da civilidade e da cidadania, da projeção desse "americano ainda interiormente inexistente”.

Paulo Prado é o único que, a meu ver, resvala para uma proposta-projeto menos definidos de revolução. Sua avaliação pessimista perante a própria situação internacional de desastre, cataclismo em preparo, recorre projetivamente à ideia poética de "revolução complexa" de Emmanuel Berl como "síntese de duas tendências opostas: esperança e revolta”.

Tal como na Utopia de More, encontramos neles a comparação espelhada de crítica à situação atual e projeção de sociedade ideal em uma mescla da racionalidade dos argumentos baseados em conceitos e informações coletadas em documentos e a ampla presença de elementos afetivos. O recurso a metáforas e outras figuras de linguagem que tocam a imaginação desenham figuras que se inscrevem nas mentes dos leitores como imagens de alto poder sugestivo. Projetos políticos que mantêm vínculos com as narrativas utópicas da cidade ideal: incitam à ação conferindo-lhe o sentido da possível configuração social e política inscrita em projeto, reiteram a necessidade de mudança, de ruptura, até. 